\title{
Megjelent az Egészségjelentés2016
}

\section{HealthReport2016 is now available}

\author{
Szerző: Varsányi Péter $\bowtie$ \\ Egészségfejlesztés folyóirat
}

Beküldve: 2017.06.07.

doi: $10.24365 /$ ef.v58i2.155

Kulcsszavak: egészségjelentés, halandóság, egészségmagatartás, elvesztett egészséges életévek, egészségveszteség

Keywords: health report, mortalitiy, health behaviour, disability adjusted lifeyears, burden of diseases

A Nemzeti Egészségfejlesztési Intézet 2016-ban is áttekintette a magyar lakosságról rendelkezésre álló legfrissebb egészségadatokat. Ennek eredményeként az év elején megjelent az Egészségjelentés2016 című tanulmány (a teljes anyag itt érhető el), amelynek dedikált célja az informált népegészségügyi döntéshozatal támogatása. A legfrissebb jelentés a 2015-ben megjelent elődjéhez hasonlóan, a magyar lakosság egészségéről nyújt helyzetképet, kiemelve a legnagyobb terhet jelentő egészségproblémákat. Időbeli és nemzetközi összehasonlításban mutatja be az egészségi állapot illetve az egészségmagatartás legfontosabb indikátorainak értékeit.

A jelentés célja, hogy a hazai egészségpolitikusok számára bővüljön a lakosság egészségére vonatkozó, a megfelelően előkészített döntéshozatalhoz szükséges információ. A jelentés adatai megerősítik, hogy indokolt folytatni az egészségügyi rendszer már megkezdett átalakításait, úgymint az erőforrások rendszeren belüli elosztásának módosítását, a szakellátás átszervezését és a népegészségügy megerősítését. Az adatok elemzésének eredményei és a nemzetközi szakirodalom áttekintése alapján a szerkesztők az alábbi, oksági láncolatba illeszkedő meg- állapításokat emelték ki a vezetői összefoglalóban. [1. ábra]

1. A magyar lakosság egészsége a legtöbb egészségmutatóban elmarad az EU fejlettebb tagországaihoz képest. Egyes keringési és rosszindulatú daganatos betegségek halálozásában egyre nő a lemaradásunk. Igen jelentős a hátrányunk az egészségügyi ellátással elkerülhető és a népegészségügyi beavatkozásokkal megelőzhető halálozásban. A halálozás mellett a csökkent életminőséget is tükröző elvesztett egészséges életévek számában is jelentősen kedvezőtlenebbek a magyar értékek, mint az EU más tagállamaiban.

2. A magyarországi egészségveszteségek döntően a viselkedéssel összefüggő kockázatokra vezethetők vissza, ahogyan ezt a magyar egészségmagatartási mutatóknak az EU-ban kirívóan rossz értékei alátámasztják. Jelentős javulást ezért csak a lakosság egészségmagatartásának megváltoztatásától lehet várni.

3. Tudományosan megalapozott, hogy a viselkedést eredményesen változtató beavatkozások egyszerre bővítik az egészséges életmóddal kap- 
csolatos ismereteket és készségeket, motiválnak életmódváltásra és biztosítják a viselkedésváltoztatást támogató társas és fizikai környezetet is.

4. Az egészségmagatartás megváltoztatásához több szektor kulcsszereplőinek összehangolt tevékenysége szükséges.

5. A társadalmi szereplők tevékenységének összehangolását országos, térségi és helyi szinten az egészségtervezés és annak megvalósítása biztosíthatja hatékonyan. Ennek feltétele a népegészségügy és az ellátó rendszer integrált, emberközpontú átalakítása. Különösen fontos a nép- egészségügy közösségi szolgáltatásainak megerősítése, mert ez képes valamennyi szinten előmozdítani a társadalmi szereplőknek az egészségtervezésben és annak megvalósításában való támogató szerepvállalását. Ehhez - és a hazai egészségügyi rendszer hatékonyságának növeléséhez - a gyógyításról a megelőzésre szükséges nagyobb hangsúlyt helyezni, és ennek megfelelően a korábbinál több erőforrást biztosítani.

6. Mivel az egészségmagatartás társadalmilag erősen beágyazott, és lassan, nehezen változtatható, ezért nagyobb hatékonyság várható a fejlődésben lévő gyermekekre fókuszáló egészségfejlesztési beavatkozásoktól.
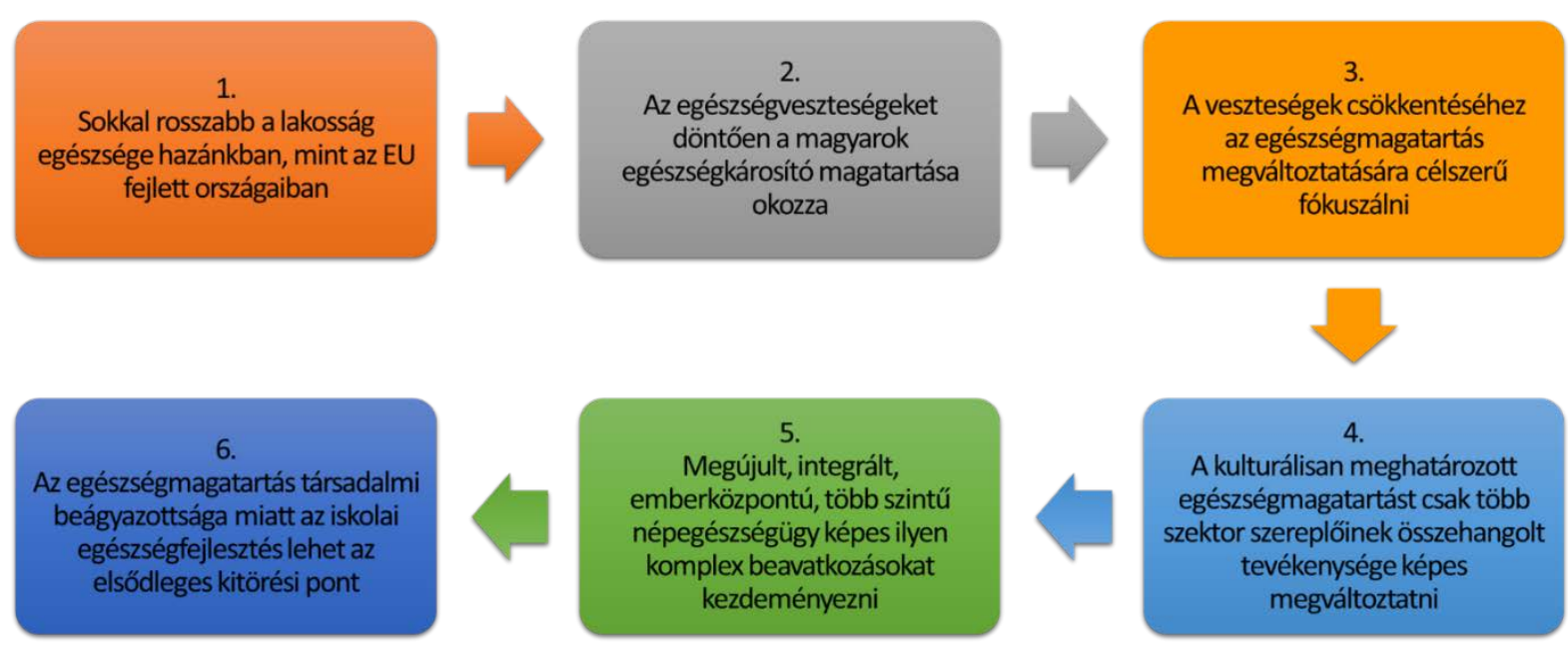

Forrás: Egészségjelentés2016 